BLS 35, No 1 2009. DOI: http://dx.doi.org/10.3765/bls.v35i1.3628

(published by the Berkeley Linguistics Society and the Linguistic Society of America)

\title{
Hypernegation, Hyponegation, and Parole Violations
}

\author{
LAURENCE R. HORN \\ Yale University
}

The classical law of Duplex negatio affirmat, adopted into English grammar by Bishop Lowth (1762), has always had its dissenters. ${ }^{1}$ While negative concord has been widely studied in the grammar of non-standard English, a number of less familiar mismatches between overt negative markers and interpretable logical negation beyond the clausal boundary emerge from the investigation of varieties of spoken English. I will briefly survey here two sets of constructions that respectively contain an apparently superfluous, uninterpreted negative marker or fail to contain an expected one. These are the two categories that I will term HYPERNEGATION and HYPONEGATION respectively. ${ }^{2}$

The most familiar variety of hypernegation is negative concord, when the expression of sentence negation spreads to indefinites within the clause, as is the rule in many Romance and Slavic languages as well as most varieties of vernacular English. Examples include (1a,b) (here and below, highlighting is added).
a. It ain't no cat can't get into no coop. (= standard Eng. 'No cat can get into any coop')
b. I can't get no satisfaction.

(Labov 1972:773)

(Jagger \& Richards 1965)

As the http://en.wikipedia.org/wiki/(I_Can't_Get_No)_Satisfaction wiki-entry on the Rolling Stones' rock anthem notes, "The title line is an example of a double negative resolving to a negative, a common usage in colloquial English."

The cross-linguistic distribution of negative concord (NC) constructions has received a good deal of attention in recent work, much of it devoted to the relation of NC to negative polarity, the interpretive status of N-WORDS (indefinites with negative force, e.g. nessuno 'nobody' and niente 'nothing' in Italian) and the

\footnotetext{
${ }^{1}$ Even when double negations affirm, there is a great deal of variation on just WHAT they affirm. The varieties of "logical double negation" and their semantic and pragmatic motivations are surveyed in Horn (1991).

2 Martin (2004) uses "hypernegation" in a different sense that traces back to the Neoplatonic tradition. The Language Loggers (cf. Zimmer 2005 and links in Whitman 2007) use OVER- and UNDERNEGATION to correspond to what I term HYPER- and HYPONEGATION respectively.
} 
diachronic reanalyses encapsulated by Jespersen's cycle. These studies include Zanuttini 1997, Martins 2000, Herburger 2001, de Swart and Sag 2002, AlonsoOvalle and Guerzoni 2002, Schwenter 2005, Falaus 2007, Espinal 1992, 2007, and Floricic and Mignon 2007 on Romance; Giannakidou 2006 on Greek; Postal 2004 on English; Zeijlstra 2007 on Dutch; Bayer 2006 on German; and Watanabe 2004 drawing on several languages. My remarks here will focus on a subtype (or constellation of subtypes) of non-cancelling negation outside the purview of $\mathrm{NC}$ that I will refer to as HYPERNEGATION.

Within this general category, Jespersen (1917:75) begins by singling out a species he terms PARATACTIC NEGATION, in which

a negative is placed in a clause dependent on a verb of negative import like 'deny, forbid, hinder, doubt.' The clause is treated as an independent sentence, and the negative is expressed as if there had been no main sentence of that particular type.

Such cases, variously termed pleonastic, expletive, or-in Smyth (1920)'s evocative term - sympathetic negation, are often attributed to the mental fusion or blend of two propositions, a positive clause in the scope of higher negation (hypotaxis) and a clause whose negative import is directly signaled (parataxis). This construction, frequent in Old English in which such verbs as tweo- 'doubt', forebead-, forber-, geswic- 'stop', and wiðcweð- 'refuse' all govern paratactic or pleonastic negation (PN), persists into Middle English and Early Modern English:

a. Nature defendeth and forbedeth that no man make himself riche.

[Chaucer]

b. First he denied you had in him no [= any] right.

[Shakespeare, Com. Errors]

c. You may deny that you were not [= that you were] the mean of my Lord Hastings late imprisonment.

[Shakespeare, Richard III]

Romance languages typically allow or require PN after verbs of fearing or forbidding, certain inherently negative adverbs (= 'unless', 'before', 'since', 'without'), and comparatives. In French, embedded clauses with (optional) pleonastic $n e$ are distinct from those with full sentential negation with ne...pas:
a. Je crains qu'il ne vienne.
'I'm afraid he's coming' (cf. Je crains qu'il ne vienne pas.
'I'm afraid he's not coming')
b. avant/à moins qu'il ne vienne
'before/unless he comes'
c. plus que je ne pensais
'more than I thought'
d. depuis que je ne t'ai vu
'since I've seen you'

In his classic study of "négation abusive," Vendryes (1950:1) rejects the more standard label of "négation explétive" for such cases on the grounds that these negations are not grammatically on all fours with, say, the expletive dative 


\section{Hypernegation, Hyponegation, and Parole Violations}

pronoun in Prends moi ça 'Take that for me', which he sees as extrinsic to the primary assertion; such a sentence telescopes the two distinct clauses 'Take that' + 'you will give me pleasure'. The negation in (3), on the other hand, is an inherent part of the expression, extending from its own domain into that of its neighbor (i.e. the embedded clause). While his label will not be adopted here (given the rather prescriptive import of abusive in English), Vendryes offers a useful catalogue of "abusive" pleonastic negation in a range of languages (Sanskrit, Ancient Greek, Latin, German, Baltic, Slavic, Amharic). His exposition of the logic of the relevant constructions recapitulates Jespersen and Benveniste: $X$ is Aer than $Y=$ ' $\mathrm{X}$ is A to an extent that $\mathrm{Y}$ is not', unless = 'if not', before = 'when still not', and so on. Typically, a main clause governing PN will imply the nonaccomplishment, falsity, or undesirability of the embedded clause. ${ }^{3}$

In addition to the contexts surveyed above, we find expletive negatives in other environments, including concessive (un)conditionals in Yiddish and Russian (courtesy of Ellen Prince and Martin Haspelmath respectively):

a. Es izmir gut vu ikh zol nit zayn. 'I'm fine wherever I am' it is to.me good where I SBJV NEG be

b. Mne xoroshogde by ja ni byl. 'I'm fine wherever I am' to.me good where SBJV I NEG be.PAST

Similarly, PN appears in main clause exclamatives and interrogatives in a variety of languages, as in the Paduan examples of (5) from Portner and Zanuttini (2000) and their now somewhat quaint English counterparts as in (6a), cited by Jespersen. Along the same lines, we can still find the upper register pleonastic negation in embedded modal contexts like (6b) in the upper literary register.

a. No ga-lo magnà tuto! NEG has-S.CL eaten everything

b. Cosse no ghe dise-lo! What NEG him say-S.CL
'He ate everything!'

'What things he's telling him!

a. How often have I not watched him!

b. The Church of England...was so fragmented that there was no knowing what some sects might not have come to believe, but he doubted whether the christening of animals was encouraged.

[P. D. James, The Children of Men, on the christening of kittens]

\footnotetext{
${ }^{3}$ Note that this formulation suggests, although it does not coincide with, anti-veridicality (Giannakidou 1998) or at least robust non-veridicality, as when verbs of doubting and forbidding are negated or questioned. As is well known, non-veridicality is also implicated in the use of the subjunctive and the distribution of negative polarity items; indeed, much recent research on negation in Romance and other languages is devoted to the exploration of the interaction of mood, NPIs, and pleonastic negation.
} 
In the examples of (3) and (6), the use of "sympathetic" negation tends to correlate with higher registers, whence the somewhat formal or archaizing feel of such turns. On the other hand, sympathetic negation is alive and well in colloquial speech, to the consternation of authorities like Fowler (1926:383-4), who disparages a negative "evoked in a subordinate clause as a mere unmeaning echo of an actual or virtual negative in the main clause" as "wrong and often destructive of the sense." Alas, he concedes, "We all know people who habitually say $I$ shouldn't wonder if it didn't turn to snow when they mean if it turned." Thus too:

a. Don't be surprised if it doesn't rain. [standard weather warning]

b. I won't be shocked if every single game is not a sellout.

[radio sports talk host Craig Carton, predicting that fans will fill

Yankee Stadium during its last year of operation in 2008]

c. I would not be surprised if his doctoral dissertation committee is not composed of members from several departments within a university. [Letter of recommendation for applicant to graduate school]

d. Don't be surprised if the Suns don't come back and push the series to five games.

[NYT story on NBA playoffs, 2 May 1991]

Along the same lines, and equally anathema to the Fowlers of the world, are the sympathetic negations after keep (NP) from and miss, (8a-c) via Google:

a. Well, really, how can I keep from not worrying?

b. I can't keep from not thinking about the impending doom of it all.

c. doing yoga every day....kept me from not thinking about dying

d. "We sure miss not seeing you every day, Bob."

[Lori Laughlin to Bob Saget on "Full House" reunion show]

On that far from infrequent miss not turn in (8d), Lederer (2008) sniffs:

Let's look at a number of familiar English words and phrases that turn out to mean the opposite or something very different from what we think they mean: I really miss not seeing you. Whenever people say this to me, I feel like responding, "All right, I'll leave!" Here speakers throw in a gratuitous negative, not, even though I really miss seeing you is what they want to say.

In fact, a Jespersen-style fusion or parataxis analysis is eminently plausible here: $(8 \mathrm{~d})=$ 'I miss seeing you' + 'I regret not seeing you'. Despite its "gratuitous" nature, the truth-conditionally pleonastic negative is not without its grammatical effect, in that the weakly negative miss cannot license NPIs without its help:

(9) I miss *(not) seeing you around anymore.

While PN is arguably grammaticalized (at least in some dialects) with surprised, keep (from), and miss, it is attested elsewhere in parole: 


\section{Hypernegation, Hyponegation, and Parole Violations}

a. I'm going to try to avoid not getting bogged down. [J. S. Horn, 1/5/09]

b. I don't know if I can hold myself back from not watching it.

[Boomer Esiason on anticipated Mets debacle, 9/17/08]

c. It's been ages since I haven't posted anything here. [Google example]

Note the parallel between the contexts in which such PNs occur in English parole and those in which pleonastic $n e$ is formally required or preferred in French, e.g. after verbs like éviter 'avoid' or adverbs like depuis 'since'. And while modern French PN takes the form of solo ne, Vendryes (1950) observes that its counterpart for the classical $17^{\text {th }}$ century dramatists Racine, Corneille, and Molière did indeed employ full sentence negation with ne...pas or ne...point, yielding all the ambiguity such constructions allow in English. To be sure, context will in general distinguish between compositional and PN readings of such embedded negations, ${ }^{4}$ and even in modern French we get triples like Prends garde de tomber, Prends garde de ne tomber, and Prends garde de ne pas tomber, all of which can only be understood as warning the hearer to take care NOT to fall.

The hackles of prescriptivists, if elevated by the pleonastic negatives of (7) and (8), are raised to the rafters by the tendency of speakers and writers to lose track of the number of negations in a sentence. If Duplex negatio affirmat, we would predict that Triplex negatio negat, and indeed we do find instances in which three semantically autonomous negatives yield the force of one negation:

a. The Mets did not not re-sign Mike Hampton because they didn't want to pay him the money. (= It wasn't because they didn't want to pay him that they didn't re-sign him.)

[Suzyn Waldman, WFAN sports radio host, 10 May 2001]

b. Even Susan Sontag, a former PEN president, who supports the leadership against Ms. Komisar,...hesitated when asked about Mr. Ovitz's role. "I'm not saying I'm not unhappy," she said, but added that quibbles might be "frivolous."

[NYT, 12 March 1997]

But given the conceptual markedness of even simple negation and its concomitant difficulty for the language processor, as verified in extensive empirical studies by Clark, Wason, and others (see Horn 1989: Chapter 3 for an overview), the interaction of the three negations is more accurately characterized as Triplex negatio confundit. The tendency for a triple negation to convey a positive is especially prevalent when at least one of the negatives is incorporated into an adverb like too or beyond or as expressed in an inherently negative predicate like surprised, avoid, deny, or doubt, as seen in the examples below (cf. also the links

\footnotetext{
${ }^{4}$ Thus, the opening line of the Hootie and the Blowfish song "I'll Come Running," "It's been such a long time since I haven't seen your face," must be interpreted compositionally, given the verses that follow, but virtually the same line occurring in a song by Ras Midas, lyrics posted at http://www.rasmidas.com/suchalongtime.html, can only have a pleonastic interpretation.
} 
at Liberman 2004 and Whitman 2007). In these cases, the reinforcing ("illogical") double negation cancels out an ordinary negation, effectively yielding a positive; alternately, one negation can be viewed as pleonastic.

(12) a. "I would not ever want to say that there are not people on our campus that at first are not hard to understand, at least until students get used to them."

[Bloomington (IL) Pantagraph, cited in The New Yorker]

b. "There isn't a man there who doesn't think they can't do it."

[Radio commentator Suzyn Waldman on Yankees' confidence, 2 Oct. 2000]

c. "I would not ever want to say that there are not people on our campus that at first are not hard to understand, at least until students get used to them," Watkins said.

[Bloomington (IL) Pantagraph, cited in The New Yorker]

d. No detail was too small to overlook.

[New Yorker 12/14/81, Words of One Syllable Department]

e. People knew too little about him not to vote against him.

[Bill Moyers on why voters in 1984 primaries voted FOR Gary Hart]

f. Nothing is too small or too mean to be disregarded by our scientific economy.

[R. H. Patterson, Economy of Capital (1865), cited in Hodgson 1885:219]

g. I can't remember when you weren't there, When I didn't care/For anyone but you...

[Opening lines of 1981 Kenny Rogers pop song "Through the Years"]

h. It's a deed that should not go unforgotten.

[Lewiston (ID) Morning Tribune, cited in The New Yorker]

i. It is not impossible that some aspect of sound-making efficiency might not have played into the mechanism of natural selection during the history of the species.

[Eric Lenneberg, Biological Foundations of Language, 1967]

j. Citing an unwillingness to not go quietly into retirement as the crowned princesses of the East, No. 1-seeded Connecticut battered No. 5 Notre Dame, 73-53.

[“Uconn's Big Message: Rout Is Just First Step," NYT 3/3/98]

k. "Let's go out and see what the boys have in store for us tonight. They've never ceased to let us down."

[Buck Showalter, Texas Rangers manager, quoted in NYT 10 Aug. 2004] 


\section{Hypernegation, Hyponegation, and Parole Violations}

It is not for nothing that Hodgson (1885:218) observes that "Piled-up negatives prove easy stumbling-blocks", 5 while Fowler (1926:375) less genially concedes that "Blunders with negatives are extremely frequent." But while, as Vendryes (1950:15) puts it, "il est naturel que les purists la $[=\mathrm{PN}]$ proscrivent au nom de la logique," we can nevertheless understand the motivation for the retention of "grammatical" PN in some languages and the periodic eruption of "ungrammatical" PN weeds in linguistic gardens elsewhere.

This emerges from the distribution of another variety of apparently redundant negation that Jespersen $(1917: 72-3 ; 1924: 334)$ dubs RESUMPTIVE negation:

[A]fter a negative sentence has been completed, something is added in a negative form with the obvious result that the negative effect is heightened...[T] he supplementary negative is added outside the frame of the first sentence, generally as an afterthought, as in "I shall never do it, not under any circumstances, no on any condition, neither at home nor abroad", etc.

In fact, the supplementary negation can precede rather than follow the main clause. Examples of both types abound in both literary and colloquial language:

a. He cannot sleep, not even after taking an opiate.

b. Not a creature was stirring, not even a mouse.

c. Not with my wife, you don't.
[Jespersen]

[C. C. Moore]

[cf. Lawler 1974]

Recent discussions of this phenomenon include those of Lawler (1974), van der Wouden (1997), and especially Dowty (2006), who persuasively makes the case for the original clause and "afterthought" as constituting separate assertions:

Resumptive Negation is an elliptical form of assertion revision: that is, it indicates a new assertion which is intended to replace the assertion made in the core clause; it may be either a strengthening or a weakening of the original assertion... Neither negation is in the scope of the other, nor is one of the negations merely pleonastic. (Dowty 2006:5-6)

A related construction is that of negative parentheticals, in which negation can appear pleonastically within a parenthetical based on one of a range of neg-raising propositional attitude predicates (believe, suppose, imagine) following the expression of main clause negation (cf. Horn 1978:190ff.):

\footnotetext{
5 Such stumbling blocks don't stop at the courthouse door. In an Alabama case from 1912 recounted by Bryant (1930: 264), Aletha Allen, a 80-year-old deaf woman, was killed by a train after having been warned not to go onto the track. When her estate sued the railway company involved, the jury acquitted the defendant, but a new trial was granted on the grounds that the jurors had been instructed to find for the defendant unless the evidence showed that the engineer did not discover the peril of the woman in time to avoid injury. The higher court invoked Triplex Negatio Confundit, ruling that both the original charge to the jury and its interpretation by the jurors was based on what was meant, not what was said. (Cf. Horn 1991 for further details.)
} 
(14) a. The Republicans aren't, I (don't) think, going to support the bill.

b. The Republicans, I (*don't) think, aren't going to support the bill.

The crusaders curiously seem inclined to take both the resumptive and parenthetical negatives of (13) and (14a) in stride. Indeed, Jespersen (1924:333-4) invokes the tacit tolerance of prescriptivists toward resumptive negation in his defense of negative concord against the standard charge of faulty logic:

No one objects from a logical point of view to "I shall never consent, not under any circumstances, neither at home nor abroad"; it is true that here pauses, which in writing are marked by commas, separate the negatives, as if they belonged to so many different sentences, while in "he never said nothing"...the negatives belong to the same sentence. But it is perfectly impossible to draw a line between what constitutes one, and what constitutes two sentences; does a sentence like "I cannot goe no further" (Shakespeare) become more logical by the mere addition of a comma: "I cannot goe, no further"?

Jespersen's quotation in this passage refers to a scene in the very same Forest of Arden that serves as a locus classicus for exhibiting the relatively free variation often attested in the distribution of hyper- and standard negation:

a. CELIA. I pray you, bear with me. I cannot go no further.

[As You Like It, from opening of II.iv in Arden Forest]

b. ADAM. Dear master, I can go no further.

[As You Like It, from opening of II.vi, in "another part of the forest"]

Relatedly, code-switching between variants is not uncommon, as when the now defunct electronics chain "The Wiz" promulgated its commercial jingle "Nobody beats the Wiz/Ain't nobody gonna beat the Wiz," presumably to capture the full range of potential consumers. Another illustration is Dylan's celebrated apothegm with its hide-and-seek NC. Pinker (2009) has recently lambasted the legal opinions of Chief Justice John Roberts for having "altered quotations to conform to his notions of grammaticality, as when he excised the 'ain't' from Bob Dylan's line 'When you ain't got nothing, you got nothing to lose'." But in the version of "Like a Rolling Stone" published in The Definitive Dylan Songbook (Dylan 2001), the original version of the line appears as "When you got nothing, you got nothing to lose." Perhaps it's not a matter of Justice Roberts removing $\mathrm{NC}$ to meet his strictures of properness as much as Mr. Zimmerman inserting NC to conform to metrical considerations and/or the perceived sociolinguistic expectations of his listeners. ${ }^{6}$

As we have seen, both PN in general and NC in particular have long aroused the purist's wrath for the arrant violation of Duplex negatio affirmat. For the

\footnotetext{
${ }^{6}$ In the other direction, Emmylou Harris's 1992 cover of Jimmy Davis's 1926 bluegrass classic "Nobody's Darling But Mine" alters the pleonastic line "Promise me that you will never/Be nobody's darlin' but mine" to "Promise me that you will always/Be nobody's darlin' but mine" in two of the three renditions of the refrain.
} 


\section{Hypernegation, Hyponegation, and Parole Violations}

linguist, negative concord - as it name suggests - is essentially no more illogical than subject-verb agreement or vowel harmony, a spreading of the negative force of a statement to indefinites within the same clause. But what of other varieties of pleonastic negation, which do not instantiate concord and, as expletive elements, might be expected to be semantically empty? Extraneous (expletive) material that results in two diametrically opposed readings for an embedded clause would appear to violate both the "Avoid ambiguity" and "Be brief" submaxims of manner (or the $\mathrm{Q}$ and $\mathrm{R}$ principles that respectively subsume them; cf. Horn 1989), so why does it not just subsist but flourish?

Psychological explanations have been offered, from Damourette and Pichon (1928) on the motivation for PN in French to Wason and Reich (1979) on the pragmatic factors facilitating the plausible but wrong interpretation of statements like No head injury is too trivial to be ignored. We have seen that the use of PN may affect NPI licensing (recall (10) above) and may also raise or lower the register, as in modern French or colloquial English. But in addition, while not affecting truth conditions, $\mathrm{PN}$ is not always semantically and pragmatically inert. ${ }^{7}$ For example, Zeijlstra (2008) observes that although standard Dutch is basically a double negation rather than NC language, it contains certain NP-internal constructions (e.g. niemand niet 'nobody not', nooit geen 'nothing no') that are understood as single but emphatic negations, rather than simply canceling out. He analyzes these as lexical items, not as true instances of NC.

In addition to such emphatic functions, $\mathrm{PN}$ may sometimes introduce presuppositions, although the data are subtle. In their influential paper on Italian comparatives, Napoli and Nespor (1976) explore the constraints on the use of what they term non $_{2}$ in comparatives and indirect questions as illustrated in (16):

a. Maria è piu intelligente di quanto \{è/non sia $\}$ Carlo.

'Maria is more intelligent than Carlo is'

b. Maria è piu intelligente di quanto tu $\{$ credi/non creda $\}$.

'Maria is more intelligent than you believe'

c. Chissà che $\{$ ti sposi/non ti sposi $\}$.

'Who knows if $\{$ he'll/he might not $\}$ marry you'

In the first two pairs, the speaker of the latter variant - with PN and subjunctive mood-presupposes that her comparative contravenes a previously held belief, while in (16c), the PN version "is used when the speaker expects the negated proposition to surprise someone, or to be contrary to prior expectations" (Napoli and Nespor 1976:836). Zanuttini (1997) offers a similar take on non $V$ mica in Italian, while Schwenter (2005) argues that the relevant property for licensing

\footnotetext{
${ }^{7}$ Indeed, it is this property that renders PN a happier fit than EN for our category, given the OED's glosses of pleonasm ('redundancy of expression either as a fault of style or as a rhetorical figure used for emphasis or clarity' [emphasis added]) and expletive ('a word or phrase...used for filling up a sentence, eking out a metrical line etc. without adding anything to the sense').
} 
secondary, non-canonical double sentential negation in Brazilian Portuguese is the discourse-old status of the proposition denied.

Other non-truth-conditional differences between unmarked and PN-bearing embedded clauses have been posited in various languages. Thus Espinal (1992:336, 1997:75) points to minimal pairs in Catalan like (17) in which the speaker of (17a) regards the arrival as likely, while the speaker of (17b) is more neutral or doubtful about the occurrence of the event.

a. Tinc por que arribaran tard. 'I'm afraid they will arrive late.' have fear that arrive+FUT late

b. Tinc por que no arribin tard. 'I'm afraid they might arrive late.' arrive $+\mathrm{SUBJ}$

More controversially, Yoon (2008) has argued that in Japanese and Korean, PN under verbs of hoping as well as verbs of fearing is associated with speaker's assessment of uncertainty and/or undesirability, but her data have been challenged by other native speakers. To be sure, as pointed out by Vendryes (1950:5), the specific conditions on the use of PN are subtle and hard to pin down. Given that a natural account of such conventional but non-truth-conditional components of speaker meaning would invoke Gricean conventional implicature, this result should not be surprising; cf. Potts (2007) and Horn (2008b) on the "descriptive ineffability" of conventional implicatures.

Besides conveying emphasis and introducing presuppositions, another function-or in any case, result - of hypernegation is to reinforce regional identity within a speech community. A shibboleth of New England speech is so don't I, or more generally so AUXn't NP. The most complete inventory for this "Massachusetts negative positive" (see 1999 cite below) is the draft entry for so that will appear in the Dictionary of American Regional English when the $4^{\text {th }}$ volume of $D A R E$ is published. ${ }^{8}$

So adv chiefly N[ew]Eng[land]

In neg constr following positive constr: used to express agreement with the positive const - often in phr so don't I 'so do I'.

1962 NYT Book Rev. 28 Jan. 16/1, This expression [= 'don't be surprised if he doesn't visit you one of these days] is akin to the old jocular negative in the following piece of dialogue: "I wish I had an orange." "So don't I." Here again, the speaker means a strong "So do I."

1980 Daily Hampshire Gaz. 9 Sept 16/2, And just as the mood of the once-solemn convocation has changed over the past few years, so hasn't the opening address by President Jill Ker Conway.

\footnotetext{
${ }^{8}$ I am grateful to DARE editor Joan Houston Hall for allowing me access to the data included here; see also the archived ads-1 threads [http://listserv.linguistlist.org/cgi-bin/wa?S1=ads-1] from 1998 to 2001, in particular the postings by Frank Abate, Jason Eisner, Beverly Flanigan, Bryan Gick, Dan Johnson, and Mark Liberman, for remarks on the origin, development, and distribution of so don't $I$ and its cousins.
} 


\section{Hypernegation, Hyponegation, and Parole Violations}

1998 NADS Letters nwPA (as of c. 1980), The standard response indicating agreement was "so don't I" (as in A: "I like ice cream." B: "Mmmm. So don't I!" Also "so didn't I", "so doesn't she", etc.)

1999 DARE File - Internet [Boston Online The Wicked Good Guide to Boston English], So don't I-An example of the Massachusetts negative positive. Used like this: "I just love the food at Kelly's." "Oh, so don't I!"

While this construction is frequently taken to be ironic (or "jocular"), both cites and speaker intuitions falsify this claim, as noted by John Lawler (p.c.), who also points out its extension to pockets (like Illinois) far from its New England base. In recent unpublished work, Jim Wood uses elicited data to argue that so don't/can't $N P$ cancels the exhaustiveness implicature of the corresponding affirmative.

Another question regarding this construction is whence. In recent work by Freeman (2004) and Pappas (2004), so do not I and the like are tracked to Shakespeare (Twelfth Night, III.iv; Richard III, I.iv, II.ii) and Beaumont \& Fletcher, with - so it is claimed - pleonastic (non-)force sometimes intended. But in fact these arguments are unconvincing. Even in the most favorable environment, the cite from Twelfth Night,

VIOLA: Methinks his words do from such passion fly, That he believes himself: so do not I.

the negation has its ordinary force. As the full context of the passage indicates, Viola's meaning here is 'I, unlike Antonio, do not (believe him)'. No fronting or inversion would be possible in this context in Present-Day English, where the only possible syntax would be I do not do so.

Midland's negative-positive answer to so AUXn't NP is the regionally restricted reading of don't care to reflected in this entry from Montgomery (2004):

care verb To be willing or agreeable to (usu. in phr. I don't care to, a response to a suggestion or invitation). The verb may range in sense from the understatement "not to mind if one does" or "to be pleased if one does."

1929 Chapman Mt Man 510 "I don't care for work" means "I like to work-I don't mind working." And "I'd not care to drive a car" means "I am not afraid to-I'd like to drive a car." Yet outlanders who have lived years in the mountains are still taking these comments in the modern sense, and advertising that the mountain man is lazy and that he is shy of modern invention.

1939 Hall Recording Speech 7 Examples of not to care to for not to mind, as in a sentence spoken by an Emerts Cove man, "She don't care to talk," meaning "She doesn't mind talking," are found in both the sixteenth and seventeenth centuries.

1998 Brewer Words of Past Another East Tennesseism is the practice, when asking somebody to do something, of adding "if you don't care to" when the meaning is exactly opposite of the plain English. An example would be, "Would you carry me to work, if you don't care to?"

In retrospect, this (non-)development should not be surprising; essentially, don't mind and don't care, compositionally equivalent, went their different ways for speakers of the standard dialect, just as horrific and terrific have become anto- 
nyms. Midland and related varieties simply preserve the status quo ante. Here is the historical record as displayed in the OED entry:

care, 4b: Not to mind (something proposed); to have no disinclination or objection, be disposed to. Now only [sic - but see above] with if, though.

1526 Pilgr. Perf. (W. de W. 1531) 18 Some for a fewe tythes, with Cayn, careth not to lese the eternall rychesse of heuen.

1597 SHAKES. 2 Hen. IV, I. ii. 142, I care not if I be your Physitian.

1611 FLORIO, Scrócca il fuso..a light-heeled trull that cares not to horne hir husband.

1748 RICHARDSON Clarissa (1811) Will you eat, or drink, friend? I dont care if I do.

Note in particular the 1611 cite, in which the complaisant trollop in question doesn't object in the least to furnishing her husband with metaphorical horns.

Another regional variant also largely localized to Midland U.S. English reflects not the negative positive but the jack-in-the-box "Positive Negative," as related in Frazier's (1997) missive from "Sure Don't America":

Normally the negative is expressed by the word "no". But for some people, and in some places, "no" is not part of the vocabulary. Instead speakers use an upbeat substitute that nevertheless conveys the same meaning - hence, the "Positive Negative". For example, if you go into a convenience store... and you ask the salesperson if they have any cat food, he or she will reply, cheerful as can be, "We sure don't!" The last word is spoken with rising inflection, as if the expression were a positive one ending with the word "do". Sometimes the word "sure" is accented with a regretful but still good-humored shake of the head... The Positive Negative can be adapted to any situation in which the answer is no: "Will you be back later?" "I sure won't!" "Can you give me a jump start?" "I sure can't".

Hypernegation proper extends from the syntactic cases we have surveyed here to lexical instances of the phenomenon. This catalogue can begin with double negative affixes with single negative meaning, as in the adjectival cases in which prefixal and suffixal negation do not cancel out. This occurred more productively in earlier ( $16^{\text {th }}$ and $17^{\text {th }}$ century) times, as seen in redundant formations like unmatchless ['unmatched', 'matchless'], unguiltless, unhelpless, unmerciless and so on (OED un', 5a; cf. also Horn 1988:224), but survives in present-day irregardless or German unzweifellos 'doubtless', lit. 'undoubtless'.

While hypernegated adjectives are now marginal, their verbal counterparts, involving an un-/de-/dis- prefixed verb that reinforces rather than reverses the meaning of the stem, are robust. Standard examples include such (ir)reversatives as unthaw (= thaw, unfreeze), unloose(n) (= loose(n), untighten), unravel, dissever, and disannul and denominals like unpeel, unshell, unpit, deworm, debone. I have argued (Horn 1988, 2002b) that these forms are motivated by the fact that un-verbs unambiguously signal a source-oriented reading in which the object or theme is returned to a state of nature (helping entropy along). A speaker may not know whether boning a chicken involves inserting or removing the bones or whether raveling the threads of a fabric entangles or disentangles them, but with deboning and unraveling only one meaning is possible. Ironically, this disambiguation function of redundant affixation has been compromised by technologi- 


\section{Hypernegation, Hyponegation, and Parole Violations}

cal advances; with the emergence of means to reverse deletions and erasures, previously entropic verbs like unerase, undelete, or unsort can now be interpreted compositionally, although the redundant readings are still attested.

We now turn to HYPONEGATION, in which there are more (rather than fewer) negatives available for interpretation than are actually expressed. Remaining within the lexical domain, consider the haplology of unpacked, as seen in (19):

(19) a. My suitcase is still unpacked and my plane leaves in an hour!

b. My boxes are still unpacked and I've been living here for a year!

In (19a), I'm not yet packed, but in (19b) I'm not yet unpacked, i.e. still packed (Horn 1988, fn. 17). Similarly, the potential threat posed by the Giants' (then) newly obtained star receiver in (19') remained un-unveiled due to his injuries.

$\left(19^{\prime}\right)$ [Because of Plaxico Burress's injuries] The big-play threat the Giants hoped he would provide Eli Manning remains unveiled.

[NYT 5 Aug. 2005, D1]

A rich crosslinguistic vein for mining both hypernegation (which doesn't count when it "should") and hyponegation (which counts when it "shouldn't") is that of the INVERSE READINGS of proximatives like almost and barely (Horn 2002a, Ziegeler 2006, Amaral 2007), where the same expression can yield either 'almost' or 'barely' (= 'almost not') interpretations, depending on the context:

Mandarin Chinese (cf. Li 1976, Biq 1989)

Wo chadianr mei chi. a. 'I almost didn't eat', 'I barely ate'

I miss-a-little not eat b. 'I almost ate' [= Wo chadianr chi le]

(21) Spanish (cf. Schwenter 2002, Pons Bordería \& Schwenter 2005)

a. Por poco sale. 'She almost left'

b. Por poco no sale. 'She almost didn't leave' (= She barely left)

a. Por poco se mata. 'She was almost killed'

b. Por poco no se mata. $\quad \neq$ (i) 'She almost wasn't killed'

$=($ ii) 'She was almost killed'

(22) Valencia Spanish (Schwenter 2002)
a. ¡Casi salgo!"
'I almost didn't get out' [lit. 'I almost get out']
b. ¡Casi llegas!
'You barely made it!' [lit., 'You almost arrive!']

While the effect in $\left(21^{\prime} b\right)$ is hypernegation, that in $(22 b)$ is hyponegation, as it is in Swiss German, where fasch normally corresponds to Standard Ger. fast 'almost' but also allows an inverted 'barely' sense. In English too, we can use near miss in a similar Janus-faced way both for disasters just avoided and goals just attained, to the consternation of language maven William Safire, whose "On 
Language" column of 2 January 2005 assails the "nonsensical" use of near miss: "Some of us patiently but uselessly pointed out that the writer meant "near hit'."

The most notorious instance of hyponegation in English is undoubtedly could care less 'couldn't care less', which dates back at least to Shirley Povich's comment in 1955 (written just before the Brooklyn Dodgers finally vanquished Stengel's Yankees in the World Series), "Casey Stengel could care less about the Dodgers' reputation for beating southpaws." I won't try to sort out the development here-sarcasm? frozen irony? reanalysis from an understood (or formerly understood) As if/Like I could care less? The sarcasm position is advocated by Pinker (1994:377) and rejected in Lawler (1974) and Liberman (2004); Liberman's Language Log post and links from it explore the intonational issue raised by Pinker as well as the formal and sociolinguistic distribution of the hyponegative.

The alternation between the equipollent variants I could care less and I couldn't care less is reminiscent of the class of SQUATITIVES (squat and its kin, including doodly-squat, diddly-shit, jack shit, zilch, beans, et al.), a set of minimizers with peculiar properties explored in Horn (2001; where the sources for (23) and (24) are provided, along with related examples) and Postal (2004); see also Postma (2001) for a related class of drecative NPIs in Dutch. A licensed squatitive is essentially an NPI like anything or a damn thing:

(23) a. He then looked into a career as a newspaper reporter but discovered writing didn't pay squat.

b. The designated hitter or DH: A player who is designated to bat for the pitcher, who, with rare exceptions, can't hit for squat.

c. We're all professionals, we understand the season's over. We happened to be 15-3, that doesn't mean squat now.

Unlicensed squat is an n-word like nothing, nada, or niente:

a. All the talk of a resurrected Yeomen football program the past two seasons will mean squat if the team fumbles its opportunity to make the playoffs.

b. When the more sophisticated students complain that they are learning squat, I would direct the professor to remind them that tutoring builds the self-esteem of both tutor and tutee.

c. My dad got'em [football tickets] for free. He works at the university. They pay him squat so they give him perks.

A unified analysis of squatitives would either take the sentences in (23) to be hypernegations or take those in (24) to be hyponegations - but not both.

In some varieties of English, one version or the other may predominate; Inspector Diamond in Peter Lovesey's mystery series is consistent in wielding his bugger alls, sod-alls, and sweet FAs as unlicensed squatitives only: 


\section{Hypernegation, Hyponegation, and Parole Violations}

a. "What did they do about it? Bugger all?" "No. They showed some responsibility."

b. "What is comes down to is the result that whatever the result it's bugger-all use without a hair from the suspect to match."

c. "Two innocent people died for bugger all?" "I'm afraid that's true."

One possible approach to could care less (CCL) would treat it essentially as a squatitive, appearing as an NPI in the scope of negation or unlicensed bearing its own negative force. This would amount to pursuing the analogy in (26):

I couldn't care less : I could care less :: It's not worth squat : It's worth squat

Postal (2004:361) collects squatitives and CCL under the same umbrella, and takes both CCL and its compositional counterpart couldn't care less to exclude negative polarity items from their scope; the judgments in (27) are Postal's.

a. She could not (*at all/*ever) care (*at all) less about their/*anyone else's agenda) (*at all).

b. She could care less about their/*anyone else's agenda) (*at all).

In fact, though, a quick googling disconfirms this claim. Among the $>1000$ Google hits for any, ever, or both in the scope of could/couldn't care less are:

(28) a. I couldn't care less about anyone or anything anymore.

b. These people clearly couldn't care less about anyone but themselves.

c. I could care less about anyone else's sexual fantasy life

d. I couldn't care less about ever going back to school.

e. I could care less about ever having a No. 1 single

f. EOM staffers could care less about ever again hearing anything about the Department of Justice's Executive Office for Immigration Review

While there are roughly twice as many hits for CCL than for its compositional counterpart, this is presumably an artifact of the current (web-attested) preference for the "illogical" formation in general. In any case, the evidence from both my own intuition and the Google hits is at odds with Postal's antipathy towards (any) NPI licensing by CCL or its negative counterpart, but consistent with his point that the presence or absence of overt negation is irrelevant.

Similar remarks apply to another classic hyponegation with a more clearly sarcastic origin: That'll teach you to $V P$ with the sense of 'that will teach you not to VP'. In Lawler 1974, the negative and hyponegative versions of this rebuke are not syntactically interchangeable, since the invisible negation in (29) fails to license even the weakest NPIs, any or ever; the indicated judgment is Lawler's. 
But in fact, precisely as with CCL, googling confirms that that'll teach you does indeed readily license NPIs like ever (1270 hits), any(thing), or both:

(30) a. "That'll teach you to ever fuck with me again," I said with a smirk.

b. Aw, sorry to hear Expatria, but that'll teach you to ever leave Boston.

c. That'll teach you to do anything without a spreadsheet.

d. That'll teach you to ever come up with anything that doesn't fit within the status quo of [sic] as defined by the internet community!

e. That'll teach him to ever say anything degrading about girls in your presence.

Nor is this surprising, since NPIs are regularly triggered in ironic or sarcastic contexts, as noted in Horn (2001):

(31) a. Fat chance I'd ever open any attachment that didn't come from one of my clients.

b. A fat lot of good THAT ever did anyone.

c. Like you'd ever lift a finger to help anyone around the house.

d. As if I give a $\{\mathbf{d a m n} / \mathbf{s h i t} /$ flying fuck $\}$ about any of that.

e. Small thanks you get for THAT, either.

Indeed, NPIs can be licensed by invisible negation in non-ironic contexts as well (see Horn 2001: §2 for additional examples, sources and extensive discussion):

(32) a. Exactly four people in the whole world have ever read that book.

b. "I'm anything but happy with THAT analysis, either."

c. "In one of the two conversations that I ever had with Raven McDavid, Jr. (this one in an elevator) he talked about feist dogs..."

d. "The tone [of an attack on manufacturers of vaginal deodorants] wasn't light-hearted, which might have justified touching the subject at all."

e. "Judge, the reason I know about this at all is by accident."

[Michael Connelly, The Brass Verdict, 2008, p. 335]

In Horn (2001) the implicit triggering effect in the contexts of (31) or (32) is dubbed FLAUBERT LICENSING, in allusion to the novelist's edict that "The artist should be in his work like God in Creation, invisible and all-powerful; let him be sensed everywhere, but let him not be seen." Like the deist God and the Flaubertian author, so too with the immanence of negativity in contexts of hyponegation: everywhere present yet nowhere visible.

In many of these contexts, there is felt to be an implicit 'only' or upper bound in the hyponegation. But not every exhaustivity-implying hyponegation licenses NPIs; clefts and other focus constructions, which have sometimes (e.g in É. Kiss 


\section{Hypernegation, Hyponegation, and Parole Violations}

1998) been analyzed as entailing and/or asserting exhaustivity, fail to license NPIs in the absence of a dedicated exhaustivity marker like only:
a. Of all our presidents, it's only [FBush] who (ever) proposed (any) tax cuts in wartime.
b. Of all our presidents, it's [FBsh] who (*ever) proposed (*any) tax cuts in wartime.
c. $\left[{ }_{\mathrm{F}} \mathrm{BUSH}\right.$ (*ever) proposed (*any) tax cuts in wartime.

The key factor here is that in the acceptable examples, the speaker's point is to assert or communicate the relevant negative proposition, which is not the case for (only-less) clefts or in-situ focus. NPIs are permitted if exhaustivity (and not just identity) is asserted, even if (as in (31) and (32)) it's not directly expressed.

While an invisible negative can license NPIs, the visible but non-functional negative of so don't I evidently cannot, as Jim Wood (p.c.) points out. As shown by examples drawn from both langue and parole, the appearance of a hypertrophic negative marker or the nonappearance of a functional one can be a poor guide to the syntactic and semantic polarity of the statement in which it occursor fails to occur. After all, negation is the un-wizzywig of grammatical categories, where all too often what you see is what you don't get - and vice versa. ${ }^{9}$

\section{References}

Alonso-Ovalle, Luis, and Elena Guerzoni. 2002. Double negatives, negative concord and metalinguistic negation. In Mary Andronis, Erin Debenport, Anne Pycha, and Keiko Yoshimura, eds., CLS 38-1: The Main Session, 15-31. Chicago: Chicago Linguistic Society.

Amaral, Patrícia. 2007. The meaning of approximative adverbs: Evidence from European Portuguese. Ph.D diss., Ohio State University.

Bayer, Josef. 2006. Nothing/nichts as negative polarity survivors? In H.-M. Gärtner, S. Beck, R. Eckardt, R. Musan and B. Stiebels, eds., Between 40 and 60 Puzzles for Krifka: A web festschrift for Manfred Krifka. Berlin: ZAS.

Biq, Yung-O. 1989. Metalinguistic negation in Mandarin. Journal of Chinese Linguistics 17:75-94.

Bryant, Margaret. 1930. English in the law courts. New York: Columbia University Press.

9 I am grateful to Patricia Amaral, David Dowty, Kai von Fintel, Joan Houston Hall, Jack Hoeksema, Beverly Flanigan, John Lawler, Mark Liberman, Michael Montgomery, Paul Postal, Chris Potts, Jim Wood, Ton van der Wouden, Ben Zimmer, Arnold Zwicky, and the audiences at the ADS (Horn 2008a) and the BLS for their examples, inspiration, and attention. The usual disclaimers apply. 
Damourette, Jacques, and Édouard Pichon. 1928. Sur la signification psychologique de la négation en français. Journal de Psychologie Normale et Pathologique 25:228-254.

Dowty, David. 2006. Resumptive negation as assertion revision. Unpublished ms., The Ohio State University.

Dylan, Bob. 2001. The definitive Dylan songbook. New York: Amsco.

É. Kiss, Katalin. 1998. Identificational focus versus information focus. Language 74:245-273.

Espinal, M. Teresa. 1992. Expletive negation and logical absorption. The Linguistic Review 9:333-358.

Espinal, M. Teresa. 1997. Non-negative negation and wh-exclamatives. In D. Forget, P. Hirschbühler, F. Martineau, and M. Luisa Rivero, eds. Negation and polarity: Syntax and semantics, 75-93. Amsterdam/Philadelphia: John Benjamins.

Espinal, M. Teresa. 2007. Licensing expletive negation and negative concord in Catalan and Spanish. In Floricic, ed., 49-74.

Falaus, Anamaria. 2007. Double negation and negative concord: The Romanian puzzle. In J. Camacho and V. Déprez, eds., Selected papers from the 36th Linguistics Symposium on Romance Languages, 135-148. Amsterdam: John Benjamins.

Floricic, Franck, ed. 2007. La négation dans les langues romanes. Amsterdam: John Benjamins.

Floricic, Franck, and Françoise Mignon. 2007. Négation et réduplication intensive en français et en italien. In Floricic, ed., 117-136.

Fowler, H. W. 1926. Modern English usage. Oxford: Clarendon Press.

Frazier, Ian. 1997. The positive negative: Saying no with a smile. Atlantic Monthly, June 1997, 24-26.

Freeman, Jason. 2004. Syntactical analysis of the "So don't I" construction. Cranberry Linguistics 2, 25-38.

Giannakidou, Anastasia. 1998. Polarity sensitivity as (non)veridical dependency. Amsterdam: John Benjamins.

Giannakidou, Anastasia. 2006. N-words and negative concord. In M. Everaert and H. van Riemsdijk, eds., The syntax companion, 3:327-391. London: Blackwell.

Herburger, Elena. 2001. The negative concord puzzle revisited. Natural Language Semantics 9, 289-333.

Hodgson, W. B. 1885. Errors in the use of English. New York: Appleton.

Horn, Laurence. 1978. Some aspects of negation. In Joseph H. Greenberg, Charles Ferguson, and Edith A. Moravcsik, eds., Syntax, vol. 4 of Universals of human language, 127-210. Stanford: Stanford University Press.

Horn, Laurence. 1988. Morphology, pragmatics, and the un-verb. In Joyce Powers and Kenneth de Jong, eds., ESCOL '88: Proceedings of the fifth Eastern States Conference on Linguistics, 210-233. Department of Linguistics, The Ohio State University.

Horn, Laurence. 1989. A natural history of negation. Stanford: CSLI, 2001. 


\section{Hypernegation, Hyponegation, and Parole Violations}

Horn, Laurence. 1991. Duplex negatio affirmat...: The economy of double negation. In Lise M. Dobrin, Lynn Nichols, and Rosa M. Rodriguez, eds., CLS 27-2: The Parasession on Negation, 78-106. Chicago: Chicago Linguistic Society.

Horn, Laurence. 2001. Flaubert triggers, squatitive negation and other quirks of grammar. In Jack Hoeksema, Hotze Rullmann, Víctor Sánchez-Valencia, and Ton van der Wouden, eds., Perspectives on negation and polarity items, 173202. Amsterdam: John Benjamins.

Horn, Laurence. 2002a. Assertoric inertia and NPI licensing. In Mary Andronis, Erin Debenport, Anne Pycha, and Keiko Yoshimura, eds., CLS 38-2: Negation and polarity items, 55-82. Chicago: Chicago Linguistic Society.

Horn, Laurence. 2002b. Uncovering the un-word: A study in lexical pragmatics. Sophia Linguistica 49:1-64.

Horn, Laurence. 2008a. Reneging: Hypernegation and hyponegation in vernacular and regional English. Paper presented to the American Dialect Society.

Horn, Laurence. 2008b. "I love me some him": The landscape of non-argument datives. In O. Bonami and P. Cabredo Hofherr, eds., Empirical issues in formal syntax and semantics, 7:169-192. http://www.cssp.cnrs.fr/eiss7.

Jagger, Mick, and Keith Richards. 1965. (I can't get no) satisfaction.

Jespersen, Otto. 1917. Negation in English and other languages. Copenhagen: Høst.

Jespersen, Otto. 1924. The philosophy of grammar. London: Allen \& Unwin.

Labov, William. 1972. Negative attraction and negative concord in English grammar. Language 48:773-818.

Lawler, John. 1974. Ample negatives. In Michael W. LaGaly, Robert A. Fox, and Anthony Bruck, eds., Papers from the Tenth Regional Meeting of the Chicago Linguistic Society, 357-377. Chicago: Chicago Linguistic Society.

Lederer, Richard. 2008. Our crazy English expressions. Vocabula Review, June 2008. Cited on http://www.vocabula.com/.

Li, Charles. 1976. A functional explanation for an unexpected case of ambiguity (S or $\sim \mathrm{S}$ ). In A. M. Devine and L. Stephens, eds., Linguistic studies offered to Joseph Greenberg, 3:527-535. Saratoga: Anma Libri.

Liberman, Mark. 2004. Caring less with stress. Language Log post, July 8, 2004. http://158.130.17.5/ myl/languagelog/archives/001182.html.

Lowth, (Bishop) Robert. 1762. A short introduction to English grammar. London: J. Hughs.

Martin, John. 2004. Themes in Neoplatonic and Aristotelian logic: Order, negation and abstraction. Aldershot, Hampshire: Ashgate.

Martins, Ana Maria. 2000. Polarity items in Romance: Underspecification and lexical change. In Susan Pintzuk, George Tsoulas, and Anthony Warner, eds., Diachronic syntax: Models and mechanisms, 191-219. Oxford: Oxford University Press.

Montgomery, Michael. 2004. Dictionary of Smoky Mountain English. Knoxville: University of Tennessee Press. 
Napoli, Donna Jo, and Marina Nespor. 1976. Negatives in comparatives. Language 52:811-838.

Pappas, Dino Angelo. 2004. A sociolinguistic and historical investigation of the "So don't I" construction. Cranberry Linguistics 2, 53-62.

Pinker, Steven. 1994. The language instinct. New York: HarperCollins.

Pinker, Steven. 2009. Oaf of office. New York Times op-ed column, January 22, 2009.

Pons Bordería, Salvador, and Scott Schwenter. 2005. Polar meaning and 'expletive' negation in approximative adverbs: Spanish por poco (no). Journal of Historical Pragmatics 6:262-282.

Portner, Paul, and Raffaela Zanuttini. 2000. The force of negation in wh exclamatives and interrogatives. In L. Horn and Y. Kato, eds., Negation and polarity, 193-231. Oxford: Oxford University Press.

Postal, Paul. 2004. The structure of one type of American English vulgar minimizer. In Skeptical linguistic essays, 159-172. New York: Oxford University Press.

Postma, Gertjan. 2001. Negative polarity and the syntax of taboo. In J. Hoeksema, H. Rullmann, V. Sa'nchez Valencia, and T. van der Wouden, eds., Perspectives on negation and polarity items, 283-330. Amsterdam: John Benjamins.

Potts, Christopher. 2007. The expressive dimension. Theoretical Linguistics 33:165-198.

Schwenter, Scott. 2002. Discourse context and polysemy: Spanish casi. In C. Wiltshire and J. Camps, eds., Romance philology and variation: Selected papers from the 30 $0^{\text {th }}$ Linguistic Symposium on Romance Languages, 161-175. Amsterdam: John Benjamins.

Schwenter, Scott. 2005. The pragmatics of negation in Brazilian Portuguese. Lingua 115:1427-1456.

Smyth, H. W. 1920. A Greek grammar. Cambridge: Harvard University Press.

de Swart, Henriëtte, and Ivan Sag. 2002. Negation and negative concord in Romance. Linguistics and Philosophy 25:373-417.

Vendryes, Joseph. 1950. Sur la négation abusive. Bulletin de la société de linguistique de Paris 46:1-18.

Wason, Peter, and Shuli Reich. 1979. A verbal illusion. Quarterly Journal of Experimental Psychology 31:591-597.

Watanabe, Akira. 2004. The Genesis of negative concord: Syntax and morphology of Negative Doubling. Linguistic Inquiry 35:559-612.

Whitman, Neal. 2007. Literal-minded archive for the over-negation category. http://iteralminded.wordpress.com/category/semantics/overnegation/.

van der Wouden, Ton. 1997. Negative contexts: Collocations, polarity and multiple negation. London: Routledge.

Yoon, Suwon. 2008. Expletive negation in Japanese and Korean. Paper presented at the $18^{\text {th }}$ Japanese/Korean Linguistics Conference. To appear in M. den Dikken and W. McClure, eds., Japanese/Korean Linguistics 18. Stanford: CSLI. 
Zanuttini, Raffaella. 1997. Negation and clausal structure: A comparative study of Romance languages. New York: Oxford University Press.

Zeijlstra, Hedde. 2007. Negation in natural language: On the form and meaning of negative elements. Language and Linguistics Compass 1:498-518.

Zeijlstra, Hedde. 2008. Emphatic multiple negative expressions in Dutch - a product of loss of negative concord. In S. Barbiers, O. Koeneman, M. Lekakou, and M.H. van der Ham, eds., Microvariations in syntactic doubling. Bingley, U.K.: Emerald Group.

Ziegeler, Debra. 2006. Interfaces with English aspect. Amsterdam: John Benjamins.

Zimmer, Ben. 2005. Negation, over- and under-. Language Log post, December 21, 2005. http://itre.cis.upenn.edu/ myl/languagelog/archives/002719.html.

Laurence R. Horn

Yale University

Department of Linguistics

P. O. Box 208366

New Haven, CT 06520-8366

laurence.horn@yale.edu 